\title{
Family firms, firm performance and political connections: Evidence from Bangladesh
}

\begin{abstract}
We investigate the role of political connections in the performance of family firms. We do so in the setting of Bangladesh, an emerging economy in which family firms are dominant and a weak regulatory environment increases the payoffs from political connections. We find that family firms perform better than nonfamily firms. Moreover, politically connected family firms outperform family firms that are not politically connected. In contrast, nonfamily firms with political connections demonstrate lower firm performance than nonfamily firms without political connections.
\end{abstract}

Keywords: Political connections, Family firms, Firm performance, Emerging economy, Bangladesh 


\section{Family firms, firm performance and political connections: Evidence from Bangladesh}

\section{Introduction}

The institutional environments in which corporations in emerging economies ${ }^{1}$ operate are vastly different from the environments in which corporations of developed economies operate. In particular, emerging economies are characterized by poorly defined property rights (La Porta et al., 1999), weak rule of law (La Porta et al., 1999), weak investor protection (La Porta et al., 2000), low quality government (La Porta, et al., 2000), lack of freedom of the press (Kaufmann et al., 2012) and poor financial transparency (Fan et al., 2011). These institutional features influence the ways in which business corporations in emerging economies operate and behave. For example, although family firms are common around the world (Hansmann and Kraakman, 2012), their presence is more prominent in emerging economies. In the U.S., family firms constitute just over $35 \%$ of the S\&P 500 firms (Anderson and Reeb, 2003), whereas in southeast Asia, the proportion of listed family firms is approximately $68 \%$ in Indonesia and $57 \%$ in Thailand and Malaysia (Claessens et al., 2000). Moreover, unlike family firms in the U.S. and the U.K., where ownership diffuses quickly after the family firms are publicly listed, family ownership in emerging economies remains highly concentrated long after going public (Fan et al., 2011).

Another key aspect in which corporations in emerging economies differ from those in developed economies is in the level of corporate political connections. Although corporate political connections appear to be widespread around the world (Faccio, 2006), they are likely to be more pronounced in emerging economies due to the institutional features of such

\footnotetext{
${ }^{1}$ We define an emerging economy as an economy that has some characteristics of a developed economy but does not meet the standards to be declared a developed economy. These economies are in a transitional phase between developing and developed status.
} 
economies, as previously presented. ${ }^{2}$ Thus, emerging economies provide a rich setting to explore the role of political connections in a market economy.

In the context of an emerging economy, we investigate (i) whether family firms perform better than nonfamily firms and (ii) whether family firms benefit more from political connections in terms of performance than do nonfamily firms. Consistent with prior research (e.g., Bartholomeusz and Tanewski, 2006; Cascino et al., 2010; Khan et al., 2015; La Porta et al., 1999; Setia-Atmaja et al., 2009; Setia-Atmaja et al., 2011), we classify a firm as a family firm if (i) the members of the same family jointly hold at least $20 \%$ of the firm's shares or voting rights, either directly or indirectly, and (ii) at least one family member is the chief executive officer (CEO) of the firm or a member of the board of directors. ${ }^{3}$ Following Faccio (2006) and Chaney et al. (2011), we consider a firm to be politically connected if at least one of its board members or the CEO is or was a member of the parliament, a minister or someone closely associated with a political party or a politician.

We conduct our study in the context of Bangladesh, an emerging economy in South Asia. We choose an emerging economy because the significance of emerging economies in the world is growing. For example, emerging economies represent $80 \%$ of the world population and produce over $45 \%$ of the world gross domestic product (GDP) ${ }^{4}$ (European Central Bank, 2014). Despite the growing significance of emerging economies, the prevalence of family firms in emerging economies and the corporate political connections in these economies, we know very little about the role of political connections in family firms. Moreover, due to institutional differences, the interaction between ownership type (family vs.

\footnotetext{
${ }^{2}$ Faccio (2006) observes that corporate political connections thrive mainly in countries with less stringent regulations on political conflicts of interest, highly corrupt countries and countries that impose restrictions on foreign investments. Mainly emerging countries exhibit these characteristics.

${ }^{3}$ La Porta et al. (1999) argue that the $20 \%$ cut-off point is usually enough for effective control of a firm. This cut-off was adopted by several studies when identifying family firms (e.g., Bartholomeusz and Tanewski, 2006; Khan et al., 2015; Setia-Atmaja et al., 2009; Setia-Atmaja et al., 2011).

${ }^{4}$ This measure is based on purchasing power parity. Using market exchange rates, this share is $30 \%$ (European Central Bank, 2014).
} 
nonfamily firms) and corporate political connections found for developed economies may not be generalizable to emerging economies.

Our choice of Bangladesh as the setting is guided by the following. First, Bangladesh exhibits many features of an emerging economy, including weak rule of law (Khan, 2003), rampant corruption (Khan, 2003), government control of the press (Reporters Without Borders, 2014) ${ }^{5}$, lack of accountability and transparency (Khan, 2003), government intervention in business activities (Fan et al., 2011) and low quality public governance (Khan, 2003). Second, as discussed in Section 2, family firms have emerged as the dominant form of ownership structure in Bangladesh, and political connections play an important role in conducting business in this country.

We analysed a sample of 654 firm-years relating to 141 unique firms listed on the Dhaka Stock Exchange (DSE) in Bangladesh for the period 2005 to 2009. We identified the political connections of the members of the boards of directors of these firms from Bangladesh Election Commission data, party websites and major national newspapers in Bangladesh. We hand collected ownership, family relations and financial data from company annual reports and prospectuses. Employing Tobin's $q$ and return on assets (ROA) as measures of firm performance, we find that family firms perform better than nonfamily firms. Moreover, family firms use their political connections to improve firm performance. On the other hand, politically connected nonfamily firms perform worse than unconnected nonfamily firms. We also find evidence that the value of political connections decays over time from first-generation firms to descendant family firms. Our results are robust to several sensitivity tests.

\footnotetext{
${ }^{5}$ In the World Press Freedom Index 2014, Bangladesh ranked $146^{\text {th }}$ among 180 countries (Reporters Without Borders, 2014). By comparison, Finland ranked $1^{\text {st }}$ (highest freedom of press) and North Korea ranked $179^{\text {th }}$.
} 
Our study extends a growing body of literature that examines the impact of political connections on firm-level behaviour and country-level policy outcomes (e.g., Adhikari et al. 2006; Bliss and Gul, 2012a, 2012b; Boubakri et al., 2008; Chaney et al., 2011; Fan et al. 2007; Gul, 2006). We extend this literature by documenting evidence that corporate political connections may have asymmetric effects on family and nonfamily firms in the political environment of an emerging economy. This finding is important given that studies on political connections in the context of developed economies provide consistent evidence of a positive effect on firm outcomes (e.g., Cooper et al., 2010; Faccio et al., 2006; Hillman, 2005). In contrast, our results suggest that political connections of nonfamily firms can lead to lower firm performance in emerging economies due to higher agency costs inside such firms and the weak institutional environment. Our study also extends the emerging literature on the role of family firms in emerging economies.

This paper proceeds as follows. Section 2 provides an overview of the institutional background of Bangladesh, while Section 3 reviews the related literature and develops the hypotheses. Section 4 describes the research design and data, and the main results are reported and discussed in Section 5. Section 6 discusses further analyses and sensitivity tests. Section 7 provides a summary of the paper and presents the conclusions.

\section{Family Firms in Bangladesh and their Political Connections}

The rise of family firms in Bangladesh and their political connections can be traced back at least to the early years of Pakistan, if not the British era. ${ }^{6}$ During Pakistan's early years, its industry policy was to promote "individual initiative and private enterprise at every

\footnotetext{
${ }^{6}$ For example, in 1943, initiatives were taken by members of a group of businessmen connected to Muhammad Ali Jinnah, Pakistan's first Prime Minister, to form a Pakistan-oriented national organization of Muslim businessmen (Papanek, 1972). This group included M. A. H. Ispahani, the founder of the Ispahani group (Papanek, 1972). At the time of the division in 1947, the Ispahanis, one of the largest Muslim industrial families in British India, moved their base from Calcutta to East Pakistan (now Bangladesh) (Kochanek, 1996). In 1971, when Bangladesh gained independence from Pakistan, unlike most Pakistani-based business houses, the Ispahanis remained behind in Bangladesh (Kochanek, 1996).
} 
stage of industrialization" (Papanek, 1972, p. 10). Such a policy encouraged individual and family businesses. In the 1960s, the military ruler Mohammad Ayub Khan further espoused the growth of family-based businesses for economic development (Wilcox, 1969). Such a philosophy benefitted the immigrant businessmen immensely (Wright, 1974). During Ayub’s regime, half of the industrial wealth was accrued by the Chiniotis of Punjab and the immigrant Memon, Bohra, and Khoja communities from the areas around Bombay, which comprised only $0.5 \%$ of the population (Dobell, 1969). At the 1968 convention of the Pakistan Management Association, Mahbub-ul-Huq, the chief economist of the Planning Commission, disclosed that $66 \%$ of the entire industrial capital of the country was concentrated in the hands of twenty families (Wilcox, 1969). "The same twenty families controlled $80 \%$ of the banking and $97 \%$ of the insurance of the country" (Wilcox, 1969, p. 91).

After Bangladesh evolved as an independent state in December 1971, many of the West Pakistani private entrepreneurs and managers (who were at the helm of both public and private enterprises in then the East Pakistan) fled the country, leaving a huge vacuum in the corporate sector. With the birth of Bangladesh, there was a clear shift in economic and social policies, and thus almost all of the large private enterprises were nationalized to promote the new government's core principle of socialism. Government ownership of industrial assets jumped from $34 \%$ in 1971 to $92 \%$ in 1972 (Humphrey, 1987). However, changes of government in 1975 led to a reversal of economic policies. When Major General Ziaur Rahman (Zia) came to power, he initiated liberal economic policies and returned some of the small companies to their Bengali owners (Uddin and Hopper, 2003). Zia also established a divestment board, which resulted in 255 state-owned enterprises being divested or privatized between 1975 and 1981 (The World Bank, 1997). 
Arguably, the industrial policy of the governments subsequent to 1975 led to the rapid growth of new family-based industrial elites (Kochanek, 1996). Family firms received a new start with the beginning of the privatization process. Many of the privatized industries were bought by families who acquired assets via alternative means and were somehow connected to the power structure. Moreover, in the context of an impoverished and fledgling capital market, the state-owned lending institutions and banks had no other option but to extend a helping hand to this 'first-generation' business class in Bangladesh. More importantly, many of the privatized industries were purchased by single owners who preferred to keep the ownership of the business within their families (The World Bank, 2009; Uddin \& Hopper, 2003). Although some of these firms eventually listed on the stock exchange in search of additional funds and lucrative capital gains, the majority of the shares were still held by the family owners. In the late 1980s, the size of this new elite was approximately 100 to 200 business groups, of which 15 to 20 were quite large (Kochanek, 1996).

While many of the new elites are drawn from the old, established business families, there is also a growing trend of new groups that have benefited from the patronage of successive governments. The leaders of the new industrial elites are active in politics, and their success often depends heavily on the political connections they maintain (Kochanek, 1996). For example, in the $9^{\text {th }}$ Parliament of Bangladesh $(2009-2013)^{7}, 59 \%$ of the elected members were businessmen (Chowdhury, 2009).

While businesses with political connections are quite common around the world (e.g., Bliss and Gul, 2012a; Faccio et al., 2006; Fan et al., 2007; Gul, 2006; Li et al., 2008), Bangladesh is an extreme case. The legal and political environments in Bangladesh perpetuate the entry of successful business families into politics and facilitate the entry of

\footnotetext{
${ }^{7}$ The January 2014 election of the $10^{\text {th }}$ parliament remains controversial, with the major opposition party, the BNP, boycotting the election and with candidates in 153 out of 300 seats being elected without competition.
} 
political leaders into business. Consequently, successful business owners easily obtain party nominations for parliamentary elections by making large donations, and political party leaders use the government machinery to maintain, defend and advance their business interests. In an analysis of publicly available data, a think-tank in Bangladesh named Shujan (Citizens' Initiative for Good Governance) found that $50 \%$ of the members of the $10^{\text {th }}$ Parliament (2014-2018) are business people and that 226 of the 350 members are Kotipoti ${ }^{8}$ (Shujan, 2014).

With the selective enforcement of laws, the absence of well-defined property rights, the political influence and interference with the judiciary system ${ }^{9}$ and the law enforcement agencies working under the directives of and very closely with the political party in power and working primarily to serve the interests of the party in power, ${ }^{10}$ political connections with the incumbent government is a precondition for business success in Bangladesh. Thus, in this country, family firms often protect and advance their economic interests through political connections. In Bangladesh, political connections serve as a substitute for investor protection, well-functioning courts and strong rule of law that investors in well-developed capital markets enjoy.

\section{Literature Review and Hypothesis Development}

\subsection{Family firms and firm performance}

\footnotetext{
${ }^{8}$ Kotipoti is a Bangla word meaning the owner of ten million Taka (Bangladesh currency). In the social context of Bangladesh, a Kotipoti is considered to be a rich person.

${ }^{9}$ The current lawsuits against H. M. Ershad, former military dictator and president, are a case in point. Although Ershard has been appointed as the Prime Minister's Special Envoy on Foreign Affairs by the new government formed after January 2014's controversial election, there are reportedly 19 lawsuits in which Ershad is a defendant or co-defendant. One is related to the killing of Major General Manzoor Ahmed, who was himself allegedly involved in killing President Ziaur Rahman. If convicted, Ershard could face a long jail term or even a death sentence. Critics argue that the lawsuits have been re-activated to "tame" Ershad politically. Interestingly, the district judge for the killing of General Manzoor was transferred on the day of judgement. Since then, the prosecution (government) attorneys have requested extended time for a "thorough investigation" of the case (Gulf Times, 11 February 2014). It is also quite common in Bangladesh for opposition leaders and activists to face "corruption charges" brought by incumbent governments.

${ }^{10}$ Bangladesh has a long history of political parties using or influencing law enforcement agencies to advance their political and commercial interests. In a recent incident, it was alleged that three members of the Rapid Action Battalion (RAB), a law enforcement agency in Bangladesh, were directly involved in the abduction and killing of seven persons, including five candidates for the local council election (The Daily Star, 13 May 2014).
} 
A family firm can be viewed as a special case of ownership concentration. Ownership concentration is likely to be high in countries with poor regulatory environments, where litigation risk is low (Monem, 2013), investor protection is weak (La Porta et al., 1998; La Porta et al., 1999), law enforcement is weak (La Porta et al., 1999) and appropriation risk is high (La Porta et al., 1998; Lee et al., 2003). Thus, family firms are likely to be more prevalent in emerging economies, such as Bangladesh.

Family firms differ from nonfamily firms in many respects. In the field of strategic management, the resource-based view of the firm (RBV) provides a theoretical framework that best explains how family firms capitalise on their uniqueness to create competitive advantage and perform better than other firms (Habbershon and Williams, 1999). The RBV posits that firms are heterogeneous and that an idiosyncratic, immobile, inimitable and often intangible bundle of resources within the firm gives it a sustainable competitive advantage and results in superior performance (Habbershon and Williams, 1999). The unique characteristics that create competitive advantage for family firms are family-oriented workplaces and greater employee loyalty (Ward, 1988), lower human resource costs (Levering and Moskowitz, 1993), lower transaction costs (Aronoff and Ward, 1995), a more trustworthy reputation (Tagiuri and Davis, 1996; Ward and Aronoff, 1991) and lower monitoring and control costs (Daily and Dollinger, 1992). As family relationships generate high levels of motivation, cement loyalties and enhance trust (Tagiuri and Davis, 1996), family firms have the ability to bring out the best in their workers (Moscetello, 1990). Furthermore, family firms are more likely to have longer investment horizons and less likely to suffer from managerial myopia (Stein, 1988) because of their focus on the interests of succeeding generations, thus resulting in greater investment efficiency. In sum, the unique characteristics listed here are likely to afford greater operating cost efficiency, higher labour 
productivity, and greater investment efficiency in family firms, which in turn results in their superior performance.

In addition, agency costs of equity are likely to be lower in these firms. ${ }^{11}$ Specifically, higher concentration of ownership, family participation in management and close monitoring of management by family members may help create a stronger alignment of incentives between owners (shareholders) and managers in a family firm (Shleifer and Vishny, 1986). ${ }^{12}$ Taken together, lower agency costs, greater operating cost efficiency, higher labour productivity and greater investment efficiency contribute to the superior performance of family firms compared to nonfamily firms. Hence, we hypothesize that

H1: Ceteris paribus, in an emerging economy, family firms outperform nonfamily firms.

\subsection{Political connections, firm performance and family firms}

Political connections may benefit a firm in several ways including government contracts, subsidies and anticompetitive favours (Baysinger, 1984), preferential tax treatment (Faccio, 2006), easier access to financing (Khwaja and Mian, 2005a), relaxed regulatory oversight (Stigler, 1971), government-sponsored bailouts (Faccio et al., 2006) and even higher IPO offer prices (Francis et al., 2009). In turn, such benefits can lead to superior performance of politically connected firms (Hillman, 2005).

Differences in performance between politically connected and unconnected firms become particularly pronounced when political links are stronger and when politically connected firms operate in countries with higher levels of corruption (Faccio, 2006), such as

\footnotetext{
${ }^{11}$ We do recognize that, in a weak regulatory environment, political connections of family firms may give rise to agency costs of debt. However, agency costs of debt are beyond the scope of this paper because we are interested in how political connections influence the performance of family firms vis-à-vis nonfamily firms. ${ }^{12}$ When ownership concentration is high, larger investors naturally have incentives to monitor management because private benefits of control largely flow to these large investors and they have much more at stake (Shleifer and Vishny, 1986). This argument clearly holds for family firms.
} 
Bangladesh, which is a country with widespread corruption (Khan, 2003). ${ }^{13}$ Thus, in an emerging country such as Bangladesh, nurturing political connections can lead to a competitive advantage that contributes to superior firm performance. In particular, political connections can help firms exploit the weaknesses in the institutional environment and derive economic benefits in the form of favourable regulation, easier access to financing, market protection, anticompetitive measures and preferential tax treatments. In sum, in a weak regulatory environment, politically connected family firms are in the best position to take advantage of the institutional environment because of the strong alignment of incentives between managers and owners within the firm. Hence, politically connected family firms are likely to perform better than politically unconnected family firms. ${ }^{14}$

Based on the above discussion, we hypothesize that

H2a: Ceteris paribus, politically connected family firms perform better than politically unconnected family firms.

Unlike that of family firms, political connections of nonfamily firms may have adverse consequences on firm performance. This is especially relevant in an emerging economic setting where there is high corruption and weak regulatory enforcement as political connections may be the source of rent-seeking behaviour of politically connected shareholders and/or managers. This outcome is likely for three reasons. First, the effect of improved firm performance on the personal wealth of a politically connected member of a nonfamily firm is likely to be diluted as a result of diffused ownership. Second, following

\footnotetext{
${ }^{13}$ According to Transparency International (TI), Bangladesh ranked $136^{\text {th }}\left(144^{\text {th }}\right)$ among 177 (174) countries in the 2013 (2012) corruption perception index (Transparency International, 2014). In the corruption perception index, the lower the rank, the higher the public perception of corruption.

${ }^{14}$ We recognize that political connections may not necessarily lead to superior firm performance. Indeed, in the presence of high agency costs and rent-seeking behaviour, political connections can lead to inferior firm performance. We argue that family ownership and family control are likely to mitigate agency costs and rentseeking behaviour. Hence, political connections of family firms are likely to lead to superior firm performance (H2a). In contrast, agency costs are likely to be high in nonfamily firms due to the nonalignment of incentives between owners and managers. Thus, the relation between politically connected nonfamily firms and firm performance is likely to be negative. This is the focus of our third hypothesis (H2b).
} 
Berle and Means (1932) and Jensen and Meckling (1976), we argue that nonfamily firms with diffused ownership and a separation of ownership from control are likely to exhibit greater conflicts of interest between owners and managers, and hence, higher agency costs, relative to those of family firms. Third, given the monitoring role of corporate governance, politically connected members of a nonfamily firm in a weak regulatory environment will try to keep the internal corporate governance structure weak and resist any measures that impinge on their rent-seeking behaviour. As Klapper and Love (2004) argue, firm-level corporate governance provisions can partially compensate for weaknesses in the legal environment; further, these provisions become more important in countries with a weak legal environment. Thus, given that rent-seeking behaviour is related to institutional inefficiency (Acemoglu and Johnson, 2004; Mauro, 1995), it is in the interest of rent-seekers to preserve institutional inefficiency or to deter any changes in the institutional environment. For example, in the Chinese setting, Chen et al. (2011) document that politically connected shareholders dominate the board of directors. Moreover, Edlin and Stiglitz (1995) argue that strategies for limiting managers' rent-seeking behaviour include strengthening the board of directors, requiring managers to own shares and improving financial reporting. ${ }^{15}$ Overall, we argue that in the institutional setting of emerging economies, politically connected members of a nonfamily firm may engage in rent-seeking behaviour and that such behaviour is detrimental to the nonfamily firm relative to other nonfamily firms that are politically unconnected. Thus, we hypothesise that

H2b: Ceteris paribus, politically connected nonfamily firms perform worse than politically unconnected nonfamily firms.

\section{Research Design}

\footnotetext{
${ }^{15}$ Note that we do not expect similar effects in a family firm because of the stronger alignment of shareholders and managers' incentives (i.e., family members participating in key management positions), the presence of majority (family) shareholders, and the personal wealth of family shareholders being tied to firm performance.
} 


\subsection{Models}

We use two alternative measures of firm performance, Tobin's $q$ and return on assets (ROA), and we measure family ownership as a continuous variable $(F O W N)$ and as a binary variable $(F F)$. Thus, we employ the following four $(2 \mathrm{X} 2)$ models to test hypothesis $1(\mathrm{H} 1)$ :

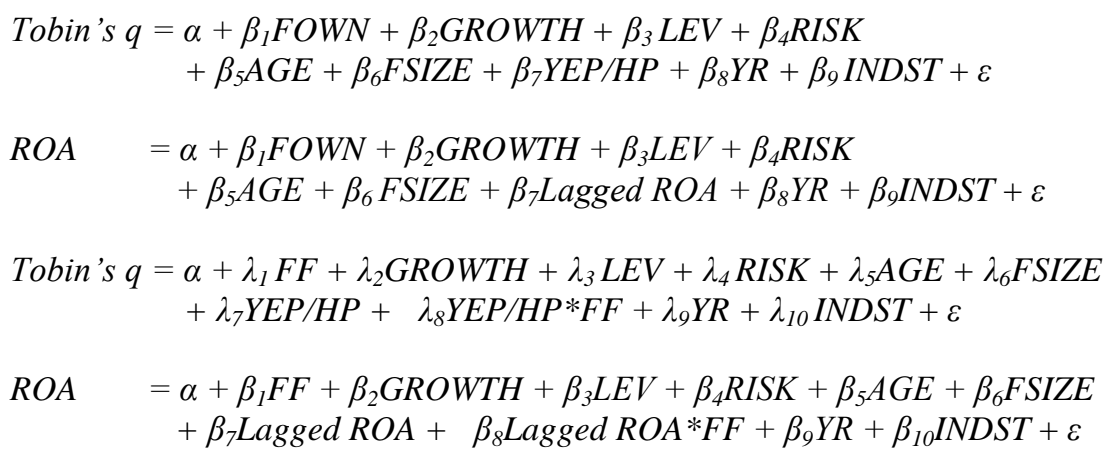

where

\begin{tabular}{|c|c|c|}
\hline obin's $q$ & $=$ & $\begin{array}{l}\text { the market value of equity plus the book value of total debt divided } \\
\text { by the book value of total assets (Setia-Atmaja et al., 2009; Wu et } \\
\text { al., 2012); }\end{array}$ \\
\hline$R O A$ & $=$ & $\begin{array}{l}\text { return on assets measured as earnings before interest and taxes } \\
\text { (EBIT) divided by the book value of total assets (Anderson and } \\
\text { Reeb, 2004; Li et al., 2008; Wu } \text { et al., 2012); }\end{array}$ \\
\hline FOWN & $=$ & percentage of shares owned by the controlling family; \\
\hline$F F$ & $=$ & $\begin{array}{l}\text { indicator variable set equal to } 1 \text { for family firms and } 0 \text { for } \\
\text { nonfamily firms; }\end{array}$ \\
\hline GROWTH & $=$ & $\begin{array}{l}\text { firm's total assets growth ratio over the last fiscal year (Black et } \\
\text { al., 2006); }\end{array}$ \\
\hline$L E V$ & $=$ & $\begin{array}{l}\text { the sum of total short-term and total long-term debt divided by } \\
\text { total assets (Bliss and Gul, 2012a); }\end{array}$ \\
\hline RISK & $=$ & $\begin{array}{l}\text { standard deviation of a firm's daily stock returns over the prior } 12- \\
\text { month period (Boone et al., 2007; Coles } \text { et al., 2008); }\end{array}$ \\
\hline$A G E$ & $=$ & $\begin{array}{l}\text { natural logarithm of the number of years since the firm was } \\
\text { incorporated (Bliss and Gul, 2012b); }\end{array}$ \\
\hline FSIZE & $=$ & natural logarithm of total assets (Gul, 2006); \\
\hline$Y E P / H P$ & $=$ & $\begin{array}{l}\text { the fiscal year-end share price of a firm scaled by its highest share } \\
\text { price within the fiscal year; }\end{array}$ \\
\hline Lagged ROA & $=$ & previous year's ROA (Dechow, Ge, and Schrand, 2010); \\
\hline$Y R$ & & \\
\hline INDST & $=$ & industry dummy; \\
\hline$Y E P / H P * F F$ & $=$ & interaction variable between $Y E P / H P$ and $F F$; \\
\hline Lagged $R O A * F F$ & & interaction variable between Lagged ROA and $F F$; and \\
\hline
\end{tabular}


We are interested in the variable $F O W N$ in models (1a) and (1b) and the variable $F F$ in models (1c) and (1d). Positive and significant coefficients of these variables would be consistent with $\mathrm{H} 1$.

Based on prior research (e.g., Anderson and Reeb, 2003; Bliss and Gul, 2012a; Li et al., 2008; Wu et al., 2012), we employ the following control variables: firm growth (GROWTH), leverage $(L E V)$, firm risk $(R I S K)$, firm age $(A G E)$ and firm size $(F S I Z E)$. Faster firm growth is likely to be positively correlated with financial performance. The leverage $(L E V)$ of a firm could lead to external corporate control (Chen and Jaggi, 2000). In particular, debt holders actively monitor the firm's capital structure to protect their interests (Hutchinson and Gul, 2004). Therefore, leverage positively influences firm performance through the monitoring activities of the debt holders. On the other hand, a negative relationship could be expected between leverage and performance according to the pecking order theory, whereby a firm prefers to fund operations from retained earnings rather than from debt and equity (Myers, 1984). Thus, the coefficient on $L E V$ could be either positive or negative.

Demsetz and Lehn (1985) argue that the higher the level of risk (RISK) in the business environment, the greater the impact of the board structure on firm value. Therefore, we expect a negative sign on the coefficient of RISK. Boone et al. (2007) argue that business complexity increases with firm age $(A G E)$. Therefore, an uncertain relationship of firm age on firm performance is expected. Furthermore, larger firms may have fewer growth opportunities (Morck et al., 1988) and more coordination problems (Williamson, 1967), which may negatively influence their performance. On the other hand, larger firms tend to make hefty investments and often receive preferential treatment, which may enhance firm performance. Thus, the coefficient on firm size (FSIZE) could be either positive or negative.

We introduce the variable $Y E P / H P$ to control for share price manipulation. In the emerging literature on share price manipulation, Comerton-Forde and Putniņš (2014) argue 
that share price manipulation on month- or quarter-end days is quite prevalent. Further, using the institutional setting of Pakistan, Khwaja and Mian (2005b) argue that the "pump and dump" type share price manipulation scheme is quite common in emerging economies where manipulators enter the market when prices are low and exit the market when prices are high. We argue that if the family firms in our sample did manipulate share price, they would have strong incentive to manipulate prices upward towards the fiscal year-end when firms face earnings announcement season. In our research setting, the variable most likely to be affected by any price manipulation is Tobin's $q$. Hence, in all models where Tobin's $q$ is the dependent variable, we incorporate the variable $Y E P / H P$. The intuition is if a family firm (or any other firm) manipulates its fiscal year-end share price, then the fiscal year-end share price is likely to be very close to its highest share price in the fiscal year.

To control for differences in earnings quality between family and nonfamily firms, we introduce Lagged ROA as a measure of earnings persistence, following Dechow, Ge and Schrand (2010). Earnings persistence is one of the fundamental properties of earnings and one of the most commonly used measures of earnings quality (Dechow et al., 2010). Finally, we use year dummies $(Y R)$ and industry dummies (INDST) to capture differential effects across years and industry sectors.

To test H2a, we estimate the following models on the full sample of 654 firm-years:

$$
\begin{aligned}
& \text { Tobin's } q=\alpha+\beta_{1} \text { FOWN }+\beta_{2} \text { PCON }+\beta_{3} \text { PCON * FOWN }+\beta_{4} \text { GROWTH }+\beta_{5} L E V+\beta_{6} \text { RISK } \\
& +\beta_{7} A G E+\beta_{8} F S I Z E+\beta_{9} Y E P / H P+\beta_{10} Y E P / H P * F O W N+\beta_{11} Y R+\beta_{12} I N D S T+\varepsilon(2 \mathrm{a}) \\
& R O A=\alpha+\beta_{1} F O W N+\beta_{2} P C O N+\beta_{3} P C O N * F O W N+\beta_{4} G R O W T H+\beta_{5} L E V+\beta_{6} R I S K \\
& +\beta_{7} A G E+\beta_{8} F S I Z E+\beta_{9} \text { Lagged ROA }+\beta_{10} \text { Lagged ROA } * \text { FOWN }+\beta_{11} Y R+\beta_{12} \text { INDST }+\varepsilon \\
& \text { Tobin's } q=\alpha+\beta_{1} F F+\beta_{2} P C O N+\beta_{3} P C O N * F F+\beta_{4} G R O W T H+\beta_{5} L E V+\beta_{6} R I S K \\
& +\beta_{7} A G E+\beta_{8} F S I Z E+\beta_{9} Y E P / H P+\beta_{10} Y E P / H P * F F+\beta_{11} Y R+\beta_{12} I N D S T+\varepsilon(2 \mathrm{c}) \\
& R O A=\alpha+\beta_{1} F F+\beta_{2} P C O N+\beta_{3} P C O N * F F+\beta_{4} G R O W T H+\beta_{5} L E V+\beta_{6} R I S K \\
& +\beta_{7} A G E+\beta_{8} F S I Z E+\beta_{9} \text { Lagged ROA }+\beta_{10} \text { Lagged ROA } * F F+\beta_{11} Y R+\beta_{12} \text { INDST }+\varepsilon
\end{aligned}
$$

where

PCON $=$ indicator variable set equal to 1 for politically connected firms 
and 0 otherwise; all other variables are as previously defined.

Our variables of interest are $P C O N^{*} F O W N$ in models (2a) and (2b) and $P C O N^{*} F F$ in models (2c) and (2d). Positive and significant coefficients of these variables would provide support for $\mathrm{H} 2 \mathrm{a}$. We test $\mathrm{H} 2 \mathrm{~b}$ by estimating the following models on the subsample of nonfamily firms:

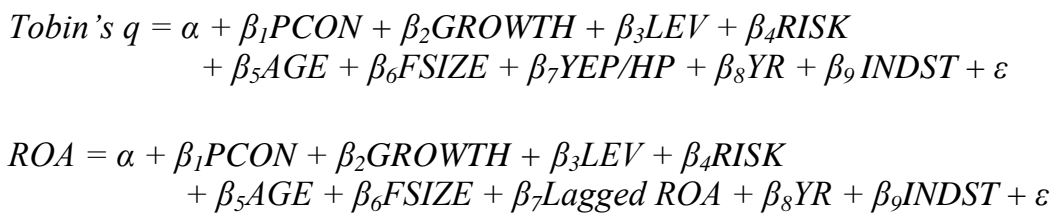

where all variables are as previously defined. We also estimate models (3a) and (3b) on the subsample of family firms to provide an additional test of H2a. For the subsample of family (nonfamily) firms, a positive (negative) and significant coefficient of PCON will be consistent with $\mathrm{H} 2 \mathrm{a}(\mathrm{H} 2 \mathrm{~b})$.

We estimate all models using the ordinary least squares (OLS) technique, and we implement White's (1980) heteroskedasticity-consistent standard errors for all regression estimates. Standard errors are clustered at the firm level.

\subsection{Data}

We collected data from multiple sources. We obtained stock price data from the DataStream database. We hand-collected family ownership, corporate governance and financial data from company annual reports. We identified family relations mainly from the disclosure of parent and spouse identity in company annual reports. Section $1.4(\mathrm{~K})$ of the Bangladesh Securities and Exchange Commission Notification of 20 February 2006 requires listed firms to disclose directors' family relations, including details about spouse and children if they are also shareholders of the firm. Moreover, we checked the reliability of our identification of relations by perusing the prospectus issued by each firm. A prospectus issued in Bangladesh contains the names, residential addresses and details of the founders, including their family members and all major shareholders of a company. 
We identified political connections of our sample firms via several steps. First, we focused on the Bangladesh national parliamentary elections surrounding the study period (2005-2009). The $8^{\text {th }}\left(9^{\text {th }}\right)$ parliamentary election was held on 1 October 2001 (28 December 2008), and the Bangladesh Election Commission (BEC) published statistical reports on these elections detailing the list of candidates (available on the BEC website). We argue that any person who contested or won in either of these two elections from any political party was politically connected, given that it is virtually impossible to receive major party nominations in Bangladesh without strong political connections. Second, we checked the names of committee members and advisory council members of political parties from party websites, in the event that they did not runs in either of these elections. Third, we matched the names of all individuals identified in these two steps with the boards of directors in our sample firms. In the case of any uncertainty, we undertook a further search in the printed and online newspapers to establish the identity of the individuals. Finally, for any politically connected director who could not be identified following the above steps, we read the business and political sections of the four most widely read English national dailies in Bangladesh (namely, The Daily Star, The Bangladesh Observer, The New Nation and The Financial Express) during the study period. Specifically, we were interested in any business or political news where the nature of the business interests of a politically connected person or the nature of political connections of a business person was reported. We then matched these news reports with the list of directors of our sample firms. ${ }^{16}$ We set the variable $P C O N$ equal to 1 for a firm-year in which we could identify the nature of the political connection of a board

\footnotetext{
${ }^{16}$ Bangladesh newspapers frequently report stories involving politicians' business interests and business people's political connections, presumably because these stories sell. For example, The Daily Star of 5 February 2007 reported business interests of several political leaders under the title "Litany of Allegations" (available at http://archive.thedailystar.net/2007/02/05/d7020501085.htm). Similarly, a recent story in the Daily Prothom Alo (31 October 2014), titled "They are company directors despite being ministers" [ মন্ত্রী হয়েও তাঁরা কোম্পানির পরিচালক] (available at http://www.prothom-alo.com/bangladesh/article/359149/).
} 
member in the sample firms and 0 otherwise. Our process of identifying political connections is consistent with that of other studies (e.g., Faccio 2006, Chaney et al., 2011).

The sample in this study comes from the firms listed on the DSE in Bangladesh. Our sample begins in 2005 and ends in 2009. In 2005, there were 282 companies listed on the DSE. Of these, 127 companies belonged to the financial sector. Consistent with previous research (Anderson and Reeb, 2003; Bliss et al., 2011), we excluded these firms because of their different regulatory environment and likely different governance structure and disclosure requirements. ${ }^{17}$ From the remaining 155 listed firms, we obtained a sample of 654 firm-years $(155$ firms X 5 years $=775$ firm-years; $775-121=654)$ due to non-availability of 121 annual reports.

Table 1 reports the sample composition by year, firm ownership, political connections and industry sector. ${ }^{18}$ Panel A lists the sample firms by ownership type (family vs. nonfamily) and by year. The sample firms vary by year with 132 firms ( 86 family firms) in 2005 to 126 (77 family firms) in 2009. Panel B shows that family firms are more likely to be politically connected than other firms. In Panel B, 260 firm-years belong to politically connected family firms out of 373 firm-years from which we could identify political connections, and 419 firm-years are related to family firms out of 654 firm-years. Independence between family firms and political connections is rejected at the $1 \%$ level by a $\chi^{2}$ test $\left(\chi^{2}=18.363\right)$. Panel $\mathrm{C}$ reports the distribution of 654 firm-years by industry sector and ownership type. In our sample, family firms appear to have the highest presence in the paper and printing industry (100\%), followed by the textile industry $(91 \%)$. In Panel $\mathrm{D}$, the paper

\footnotetext{
${ }^{17}$ As per the Bangladesh Companies Act 1994, there is no restriction on share ownership for family members. In contrast, as per section 14A of the Bangladesh Banking Company Act 1993, the members of a family, either individually or jointly cannot own more than $5 \%$ of the shares of a bank. Because we have used a $20 \%$ ownership threshold to identify family firms, public banks and financial institutions are excluded from our sample. Furthermore, as per section 15 of the Banking Company Act, the appointment and removal of directors, CEOs, or managing directors of a bank (other than specialized and new banks) require the approval of the Bangladesh central bank. However, non-financial companies do not require such approvals.

${ }^{18}$ The DSE has its own industry sector classification scheme, as reported in Table 1.
} 
and printing industry again appears to be the most politically connected industry (100\%), followed by the cement industry $(81 \%)$. These results are likely because the Bangladesh government is a large consumer of printing services and undertakes large infrastructure projects.

\section{<Table 1 about here>}

\section{Results}

\subsection{Descriptive statistics}

Table 2 presents descriptive statistics of the variables based on the full sample of 654 firm-years. Among the key variables, the mean (median) Tobin's $q$ is 1.508 (1.118), and the mean (median) $R O A$ is $0.073(0.070)$. The mean of FOWN suggests that, on average, $29.0 \%$ (median $=31.9 \%$ ) of firm shares are held by the controlling family. On the other hand, the mean of $F F$ indicates that $64.1 \%$ of the observations are classified as family firm-years. The existence of some level of political connection $(P C O N)$ is traced in $57 \%$ of the observations.

In a series of untabulated tests, comparing family firms with nonfamily firms suggest several differences between these two groups. First, family firms perform significantly better than nonfamily firms in terms of Tobin's $q$ but not in terms of ROA. In our sample, the mean (median) Tobin's $q$ of 1.769 (1.340) in family firms is significantly higher than that of 1.362 (1.065) in nonfamily firms $(p<0.001)$. However, family firms are younger than nonfamily firms with a mean (median) $A G E$ of 21.303 (22.000) years, which is significantly lower than the mean (median) $A G E$ of 25.996 (26.000) years for nonfamily firms $(p<0.001)$. Another key dimension in which these two groups of firms differ is in the level of political connections $(P C O N)$ as the level of political connections is significantly higher in family firms $(63 \%$ of the observations) compared with that in nonfamily firms $(46 \%)(p<0.001)$. Among the other variables, although the mean RISK is not significantly different between the two groups $(p=0.126)$, the median RISK in family firms $(0.026)$ is significantly lower $(p<$ 
0.001) than that in nonfamily firms (0.029). Moreover, the mean Tobin's $q$ of 1.433 in politically connected $(P C O N)$ firms is significantly lower than that of 1.607 in politically unconnected $(N P C)$ firms $(p<0.001)$. Similarly, the mean $R O A$ of 0.070 in $P C O N$ firms is lower than that of 0.078 in NPC firms $(p=0.012)$. Moreover, PCON firms are younger than $N P C$ firms $(p<0.001)$ with the mean age of PCON (NPC) firms being 22.385 (23.715) years. On the other hand, the median PCON firm is larger in size $(p<0.001)$ and more leveraged $(p$ $=0.046)$ than the median NPC firm.

\section{<Table 2 about here >}

Table 3 provides the Pearson's correlation matrix for the key variables in the study. As reported in Table 3, Tobin's $q$ appears to be significantly negatively correlated ( $r=-0.071)$ to political connections $(P C O N)$ at the $10 \%$ level $^{19}$ and positively correlated $(r=0.577)$ to leverage $(L E V)$ at the $1 \%$ level. These results are consistent with the univariate test results when PCON and NPC firms are compared. Return on assets $(R O A)$ is positively related $(r=$ $0.084)$ to family ownership $(F O W N)$ at the $5 \%$ level. $R O A$ is also positively related $(r=$ $0.102)$ to firm growth $(G R O W T H)$ and positively related $(r=0.103)$ to firm size $(F S I Z E)$ at the $1 \%$ level. On the other hand, $R O A$ is negatively related $(r=-0.406)$ to leverage and firm risk $(r=-0.134)$, with both correlations being significant at the $1 \%$ level. PCON appears to be positively correlated to both the continuous $(F O W N)$ and binary $(F F)$ measures of family ownership ( $r=0.189$ and 0.168 , respectively). However, RISK and AGE appear to be negatively correlated to both $F O W N(r=-0.114$ and -0.180$)$ and $F F(r=-0.117$ and -0.097$)$, respectively, with all correlations being significant at the $1 \%$ level. $Y E P / H P$, our proxy for share price manipulation, appears to be positively correlated to $R O A(r=0.193)$ but negatively correlated to RISK $(r=-0.284)$ at the $1 \%$ level. These results are expected as higher firm performance $(R O A)$ should lead to a higher year-end share price, and thus, stock

\footnotetext{
${ }^{19}$ All tests in this paper are two-tailed tests.
} 
return volatility would be inversely related to share price on a given day. $Y E P / H P$ is also positively correlated to family firms $(F F, r=0.075)$ and firm $A G E(r=0.077)$ at the $10 \%$ level. Overall, the correlations reported between our variables are as expected.

\section{$<$ Table 3 about here $>$}

\subsection{Family firms and firm performance}

Table 4 reports the OLS estimates of models (1a), (1b), (1c), and (1d) for testing the association between family firms and firm performance (H1). Our variable of interest is family firm as proxied by the continuous measure FOWN in models (1a) and (1b) and the binary measure $F F$ in models (1c) and (1d). As Table 4 reveals, the coefficients of $F O W N$ (= $0.347,0.012)$ are positive, as predicted, and significant $(p=0.041,0.039)$ in both models (1a) and (1b), respectively. We also find that the coefficients of $F F$ are positive, as predicted, and significant (in model $(1 \mathrm{c}): F F=0.253, p=0.025$; in model $(1 \mathrm{~d}): F F=0.008, p=0.047$ ). Thus, across all four models, the results consistently show that family firms perform better than nonfamily firms, thus supporting H1. These significant results for family firms are obtained even after controlling for potential share price manipulation that may inflate Tobin's $q$ and earnings manipulation that may inflate ROA. Specifically, in model (1a), the coefficient of $Y E P / H P(=0.772)$ is positive and significant $(p<0.001)$, and in model $(1 \mathrm{c})$, the coefficient of $\mathrm{YEP} / H P^{*} F F(=1.118)$ is positive and significant $(p=0.057)$. That is, family firms have a relatively higher year-end share price compared with that of nonfamily firms. However, compared with nonfamily firms, family firms do not appear to have lower earnings persistence as measured by Lagged ROA. In models (1b) and (1d), the coefficients of 0.773 and 0.803 on Lagged ROA are positive and significant ( $p<0.001,0.001)$, respectively); however, the interaction variable Lagged $R O A * F F$ in model (1d) (coefficient $=-0.051, p=$ 0.326) is not significant. 
In Table 4, among the other control variables, leverage $(L E V)$ has a positive effect (coefficient $=0.923,0.874 ; p<0.001,0.001)$ on Tobin's $q$ in models (1a) and (1c) but a negative effect on $R O A$ (coefficient $=-0.017,-0.011 ; p<0.001,0.001)$ in models $(1 \mathrm{~b})$ and (1d), respectively. RISK (coefficient $=-0.152, p=0.093$ ) has a negative effect on $R O A$ only in model (1b), whereas $A G E$ (coefficient $=-0.019, p<0.001$ ) has a negative effect on Tobin's $q$ only in model (1c). On the other hand, there is some evidence that larger firms perform better as indicated by positive and significant coefficients of FSIZE (coefficient $=0.007, p=$ 0.017 ; coefficient $=0.008, p=0.028$ in models $(1 \mathrm{~b})$ and $(1 \mathrm{~d})$, respectively). Overall, the explanatory powers of the accounting-based models are higher than those of the market-based models (Adjusted $R^{2}$ of $65 \%$ in model (1b) and $67 \%$ in (1d) compared with $46 \%$ in model (1a) and $52 \%$ in model (1c)). In sum, we find strong evidence that family firms perform better than nonfamily firms even after controlling for earnings persistence, as a proxy of earnings quality, and plausible share price manipulation by family firms. The differential results for $L E V$ across models suggest that the capital market evaluates a firm's debts more positively, thereby pre-empting future growth opportunities, relative to debts' implications for accounting-based firm performance.

\section{<Table 4 about here>}

Table 5 reports the OLS estimates of models (2a), (2b), (2c) and (2d) for testing H2a on the full sample and the OLS estimates of models (3a) and (3b) for testing H2a (on family firms only) and $\mathrm{H} 2 \mathrm{~b}$ (on nonfamily firms only). In Table 5, our variables of interest are PCON and the interactions of PCON with family ownership (i.e., PCON*FOWN and $P C O N^{*} F F$ ). We find that $P C O N$ is consistently negative and significant in all four models (i.e., (2a), (2b), (2c) and (2d)) for the full sample with a coefficient ( $p$-value) of -0.154 (0.071), $-0.006(0.041),-0.334(0.009)$ and $-0.006(0.036)$, respectively. In contrast, the coefficients of the interaction terms $P C O N^{*} F O W N$ in models $(2 \mathrm{a})$ and $(2 \mathrm{~b})$ (coefficient $=$ 
0.093, 0.011; $p=0.065,0.059$, respectively) and $P C O N^{*} F F$ in models (2c) and (2d) (coefficient $=0.311,0.009 ; p=0.054,0.075$, respectively) are positive, as expected, and significant. These results clearly demonstrate that, while political connections generally decrease firm performance, they have a positive effect on the performance of family firms. Thus, H2a is supported.

In Table 5, when the full sample is partitioned into family firms (419 firm-years) and nonfamily firms (235 firm-years), the coefficients on PCON are significantly positive for family firms (coefficient ( $p$-value) of $0.026(0.077)$ and $0.001(0.089)$ in models (3a) and (3b), respectively). In contrast, the coefficients on $P C O N$ are significantly negative for nonfamily firms (coefficient ( $p$-value) of $-0.368(0.016)$ and $-0.011(0.018)$ in models (3a) and (3b), respectively). These results suggest that political connections help family firms improve their performance, whereas the performance of nonfamily firms worsens with political connections. These results are consistent with the predictions of both $\mathrm{H} 2 \mathrm{a}$ and $\mathrm{H} 2 \mathrm{~b}$. In Table 5, the results for the control variables in the full sample as well as the subsamples are largely consistent with those reported in Table 4 . Taken together, the results in Table 5 clearly suggest that while family firms are better off with political connections in terms of improving firm performance, nonfamily firms are worse off when they have political connections.

\section{<Table 5 about here>}

\section{Further Analysis}

\subsection{Impact of family generations on firm performance}

Previous studies (e.g., Morck et al., 1988; Perez-Gonzalez, 2006) suggest that generations of family firms may have a different impact on firm performance. Following this line of argument, we extend our analysis to explore whether family generations in Bangladesh have any impact on the performance of family firms. Accordingly, we classify a 
family firm as a 'first-generation' firm when a founder or co-founder is the CEO or chairman of the board and all other family firms as 'descendant' firms. Next we estimate the following models for the subsample of family firms only (419 firm-years) after introducing a dummy variable to capture whether a family firm is a 'first-generation' firm:

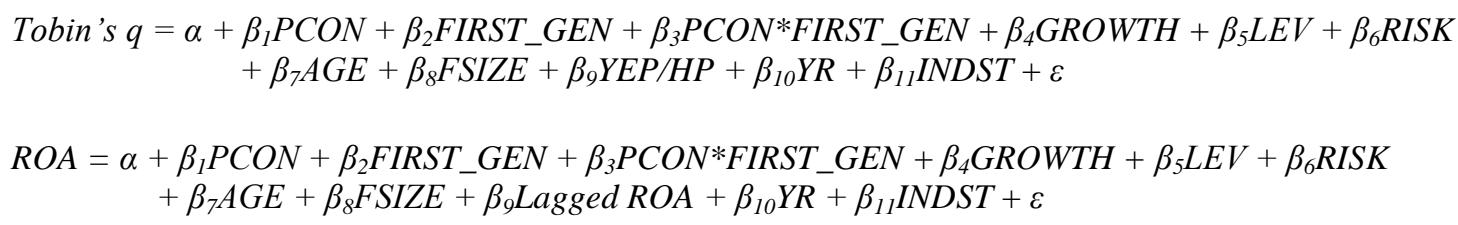

where FIRST_GEN is a dummy variable set equal to 1 for 'first-generation' family firms and 0 otherwise, PCON*FIRST_GEN is the interaction term between PCON and FIRST_GEN and all other variables are as previously defined.

Table 6 reports the OLS estimates of models (4a) and (4b). In the 'all family firms' subsample, the coefficients on $P C O N(=0.289,0.013)$ are positive and significant $(p=0.097$, 0.067, respectively); these results are consistent with prior results on family firms reported in Table 5. The coefficients on our variable of interest, PCON*FIRST_GEN $(=0.396,0.298)$, are positive and significant $(p=0.053,0.076$, respectively). These results suggest that 'firstgeneration' family firms improve their performance via political connections, and the results for the control variables are consistent with prior results.

We also estimate the following two models for the two subsamples of 'first-generation' (305 firm-years) and 'descendant' family firms (114 firm-years) to test further the effect of family generation on firm performance:

$$
\begin{aligned}
\text { Tobin's } q= & \alpha+\beta_{1} P C O N+\beta_{2} G R O W T H+\beta_{3} L E V+\beta_{4} R I S K \\
& +\beta_{5} A G E+\beta_{6} F S I Z E+\beta_{7} Y E P / H P+\beta_{8} Y R+\beta_{9} I N D S T+\varepsilon \\
\text { ROA }=\alpha+ & \beta_{1} P C O N+\beta_{2} G R O W T H+\beta_{3} L E V+\beta_{4} R I S K \\
+ & \beta_{5} A G E+\beta_{6} \text { FSIZE }+\beta_{7} \text { Lagged ROA }+\beta_{8} Y R+\beta_{9} I N D S T+\varepsilon
\end{aligned}
$$

where all variables are as previously defined.

The results of estimating models (4c) and (4d) are also reported in Table 6. In the subsample of 'first-generation' family firms, the coefficients on $\operatorname{PCON}(=0.037,0.001)$ are significantly 
positive ( $p=0.075,0.089$, respectively). In contrast, in the subsample of 'descendant' family firms, the coefficients on $P C O N(=-0.288,-0.232)$ are significantly negative $(p=0.026$, 0.087, respectively). These results suggest that the value of political connections in family firms decays over time. That is, the descendants of a politically connected business person may not be able to maintain the same relationship due to the personal nature of political connections. The differential effects of family ownership (whether 'first-generation' or 'descendant'), as reported in Tables 5 and 6, are consistent with those of Villalonga and Amit (2006). In the U.S. setting, they found that family ownership creates value only when the founder serves as the CEO of the family firm or the chairman with a hired CEO (i.e., firstgeneration firms) and that descendant-CEOs destroy firm value.

\section{<Table 6 about here>}

\subsection{Robustness checks}

W conducted several tests to verify the robustness of our results, but for brevity, we do not tabulate the results. First, in the finance literature, it is well documented that ownership concentration and firm performance/value have a non-linear relationship if the incentive structure of the equity holder changes as holdings change (e.g., Anderson and Reeb, 2003; Pindado, Requejo and de la Torre, 2008; McConnell and Servaes, 1990; Morck et al., 1988). Thus, following Anderson and Reeb (2003) and McConnell and Servaes (1990), we include FOWN and the square of FOWN in models (1a) and (1b) to test for a nonlinear relationship between family ownership and firm performance. In both models, we find that family ownership $(F O W N)$ has a significantly positive coefficient. However, family ownership squared has a negative coefficient, albeit it is not significant. 
Second, elections for the $9^{\text {th }}$ national parliament of Bangladesh were held in 2008, which is a sample year in this study. Because an election year may escalate corporate political connections through donations to party campaign funds, we substitute the year dummies in models (1a), (1b), (1c), and (1d) with a dummy variable for the election year (set equal to 1 for 2008 and 0 for all other years). We find that the results remain consistent with our main findings and that the new dummy variable is not significant. Third, it may be argued that contemporaneous relations are inappropriate for examining any association between corporate political connections and firm performance given the time managers need to improve performance using political connections. Accordingly, we lag the political connections variable by one year to allow for the effect of any change in firm performance but find no qualitative differences from the results reported earlier. Finally, we use a fixed effects model to address the possibility of a spurious relation between the dependent and the independent variables due to unobserved firm heterogeneity. All of our results remain qualitatively similar.

\section{Conclusions}

In the context of Bangladesh, an emerging economy in South Asia, we investigate whether family firms perform better than nonfamily firms and whether family firms benefit more from political connections in terms of performance than do nonfamily firms. We choose an emerging economy as our research setting because both political connections and family firms are prevalent in emerging economies. Moreover, despite the growing importance of emerging economies, we know very little about the role of political connections and family firms in these economies. We choose Bangladesh as our setting because it exhibits many features of emerging economies, including weak rule of law, widespread corruption, poor investor protection and lack of freedom of the press. 
Our results show that family firms perform better than nonfamily firms, even after controlling for earnings quality and plausible share price manipulation by family firms. Although we find some evidence that is consistent with family firms manipulating share price, these firms exhibit some evidence of higher earnings persistence. Overall, our results are consistent with the alignment argument, which suggests that because of a family's longterm focus and strong motivation to pass the family wealth to future generations, family members maximise firm performance to maximise their own family wealth. We also document that political connections per se have an adverse impact on the performance of firms, a result that is consistent with the argument that in emerging economies where there is a weak regulatory environment and poor investor protection, the business elites potentially exploit their political linkages to influence the system in accumulating their own wealth at the expense of general shareholders (Li et al., 2008). Thus, politically connected firms appear to bear the costs of creating connections with politicians and those affiliated with political parties.

In relation to politically connected family firms, we find that these firms perform better than unconnected family firms. In contrast, politically connected nonfamily firms perform worse than unconnected nonfamily firms. With respect to family generations, we find that while political connections are beneficial for first-generation family firms, they are detrimental to firm performance in the descendant family firms.

Because political connections can give rise to corruption and anti-competitive behaviour and can stifle allocative efficiency in an economy, politically connected firms may grow at the expense of firms that are politically unconnected. Empirical evidence in this paper suggests that nonfamily firms in emerging economies should not hire politically connected managers. In developed market economies, a strong institutional setting and strong corporate governance may help shareholders monitor politically connected members in 
business against their potential rent-seeking behaviour and their risk of wealth expropriation. However, in emerging economies, absent a strong institutional environment and strong firmlevel internal governance, political agents may engage in wealth expropriation at the expense of other shareholders.

However, the results of this study must be interpreted with caution in light of several limitations. First, our concept of family firm is based on publically available data. We did not systematically assess differences in the extent of family members' involvement in fostering political connections or in motivations of family members across generations. Furthermore, the dataset at hand does not allow us to test specific benefits of political connections that accrue for politically connected firms. Nevertheless, our analysis provides clear evidence that political connections in emerging economies can have a differential impact on the performance of family and nonfamily firms. 


\section{References}

Acemoglu, D., Johnson, S., 2004. Institutions as fundamental cause of long-run growth, NBER Working Papers Series 10481.

Adhikari, A., Derashid, C., Zhang, H., 2006. Public policy, political connections, and effective tax rates: Longitudinal evidence from Malaysia. Journal of Accounting and Public Policy 25(5), 574-595.

Anderson, R. C., Reeb, D. M., 2003. Founding-family ownership and firm performance: Evidence from the S\&P 500. Journal of Finance 58(3), 1301-1328.

Anderson, R. C., Reeb, D. M., 2004. Board composition: Balancing family influence in S\&P 500 firms. Administrative Science Quarterly 49(2), 209-237.

Aronoff, C.E., Ward, J.L., 1995. Family-owned businesses: A thing of the past or a model of the future? Family Business Review 8(2), 121-130.

Bangladesh Securities and Exchange Commission. 2006. Notification No. SEC/CMRRCD/2006-158/Admin/02-08 of 20 February 2006.

Bartholomeusz, S., Tanewski, G. A., 2006. The relationship between family firms and corporate governance. Journal of Small Business Management 44(2), 245-267.

Baysinger, B. D. 1984. Domain maintenance as an objective of business political activity: An expanded typology. Academy of Management Review. 9(2), 248-258.

Berle, A. A., and Means, G. C. 1932. The modern corporation and private property. Macmillan: New York.

Black, B. S., Jang, H., Kim, W. 2006. Predicting firms' corporate governance choice: Evidence from Korea. Journal of Corporate Finance. 12(3), 660-691.

Bliss, M. A., Gul, F. A., Majid, A. 2011. Do political connections affect the role of independent audit committees and CEO Duality? Some evidence from Malaysian audit pricing. Journal of Contemporary Accounting \& Economics, 7(2), 82-98.

Bliss, M. A., Gul, F. A., 2012a. Political connection and leverage: Some Malaysian evidence. Journal of Banking and Finance 36(8), 2344-2350.

Bliss, M. A., Gul, F. A., 2012b. Political connection and cost of debt: Some Malaysian evidence. Journal of Banking and Finance 36(5), 1520-1527.

Boone, A. L., Field, L. C., Karpoff, J. M., Raheja, C. G., 2007. The determinants of corporate board size and composition: An empirical analysis. Journal of Financial Economics 85(1), 66-101.

Boubakri, N., Cosset, J., Saffar, W., 2008. Political connections of newly privatized firms. Journal of Corporate Finance 14(5), 654-673. 
Cascino, S., Pugliese, A., Mussolino, D., Sansone, C., 2010. The influence of family ownership on the quality of accounting information. Family Business Review 23(3), 246-265.

Chaney, P. K., Faccio, M., Parsley, D., 2011. The quality of accounting information in politically-connected firms. Journal of Accounting and Economics 51(1-2), 58-76.

Chen, C. J. P., Jaggi, B., 2000. Association between independent non-executive directors, family control and financial disclosures in Hong Kong. Journal of Accounting and Public Policy 19(4-5), 285-310.

Chen, C. J. P., Li, Z., Su, X., Sun, Z., 2011. Rent-seeking incentives, corporate political connections, and the control structure of private firms: Chinese evidence. Journal of Corporate Finance 17(2), 229-243.

Chowdhury, F. D. 2009. Problems of women's participation in Bangladesh politics. The Round Table, 98(404), 556-567.

Claessens, S., Djankov, S., Lang, L. H. P., 2000. The separation of ownership and control in East Asian corporations. Journal of Financial Economics 58(1-2), 81-112.

Coles, J. L., Daniel, N. D., Naveen, L. 2008. Boards: Does one size fit all? Journal of Financial Economics, 87(2), 329-356.

Comerton-Forde, C., Putiniņš, T. 2014. Stock price manipulation: Prevalence and determinants. Review of Finance 18(1), 23-66.

Cooper, M. J., Gulen, H., Ovtchinnikov, A. V., 2010. Corporate political contributions and stock returns. The Journal of Finance 65(2), 687-724.

Daily, C.M., Dollinger, M.J., 1992. An empirical examination of ownership structure in family and professionally managed firms. Family Business Review 5(2), 117-136.

Dechow, P., Ge, W., Schrand, C. 2010. Understanding earnings quality: A review of the proxies, their determinants and their consequences. Journal of Accounting and Economics 50, 344-401.

Demsetz, H., Lehn, K., 1985. The structure of corporate ownership: Causes and consequences. Journal of Political Economy 93(6), 1155-1177.

Dobell, W. M. 1969. Ayub Khan as president of Pakistan. Pacific Affairs 42(3) 294-310.

Edlin, A. and Stiglitz, J.E. 1995. Discouraging rivals: Managerial rent-seeking and economic inefficiencies. American Economic Review 85(5), 1301-1312.

European Central Bank, 2014. Emerging economies. Available at http://www.ecb.europa.eu/ecb/tasks/international/emerging/html/index.en.html (last accessed on 24 March 2014).

Faccio, M., 2006. Politically-connected firms. American Economic Review 96(1), 369-386. 
Faccio, M., Masulis, R. W., McConnell, J. J., 2006. Political connections and corporate bailouts. Journal of Finance 61(6), 2597-2635.

Fan, J. P. H., Wei, K. C. J., Xu, X., 2011. Corporate finance and governance in emerging markets: A selective review and an agenda for future research. Journal of Corporate Finance $17,207-214$.

Fan, J. P. H., Wong, T. J., Zhang, T., 2007. Politically-connected CEOs, corporate governance, and post-IPO performance of China's newly partially-privatized firms. Journal of Financial Economics 84(2), 330-357.

Francis, B. B., Hasan, I., Sun, X., 2009. Political connections and the process of going public: Evidence from China. Journal of International Money and Finance 28(4), 696-719.

Gul, F. A., 2006. Auditors' response to political connections and cronyism in Malaysia. Journal of Accounting Research 44(5), 931-963.

Gulf Times, 2014, http://www.gulf-times.com/bangladesh/245/details/380773/relief-forershad-as-verdict-on-1981-manzoor-murder-case-deferred (last accessed on 23 March 2014)

Habbershon, T.G., Williams, M.L. 1999. A resource-based framework for assessing the strategic advantages of family firms. Family Business Review 12(1), 1-25.

Hansmann, H., Kraakman, R., 2012. Reflections on the end of history of corporate law, in "The Convergence of Corporate Governance: Promise and Prospects" edited by Rasheed A.A., and Yoshikawa, T., Palgrave Macmillan, Hampshire, U.K.

Hillman, A. J., 2005. Politicians on the board of directors: Do connections affect the bottom line? Journal of Management 31(3), 464-481.

Humphrey, C., 1987. Privatization in Bangladesh. Working Paper, United States Agency for International Development, Washington DC.

Hutchinson, M., Gul, F. A., 2004. Investment opportunity set, corporate governance practices and firm performance. Journal of Corporate Finance 10(4), 595-614.

Jensen, M.C., Meckling, W.H., 1976. Theory of the firm: Managerial behaviour, agency costs and ownership structure. Journal of Financial Economics 3(4), 305-360.

Kaufmann, D., Kraay, A., Mastruzzi, M. 2012. The Worldwide Governance Indicators, Available at http://info.worldbank.org/governance/wgi/index.asp

Khan, M. M., 2003. State of governance in Bangladesh. The Round Table: The Commonwealth Journal of International Affairs 91(370), 391-405.

Khan, A., Muttakin, M. B., Siddiqui, J., 2015. Audit fees, auditor choice and stakeholder influence: Evidence from a family-firm dominated economy. British Accounting Review, in press.

Khwaja, A. I., Mian, A., 2005a. Do lenders favour politically-connected firms? Rent provision in an emerging financial market. Quarterly Journal of Economics 120(4), 13711411. 
Khwaja, A. I., Mian, A., 2005b. Unchecked intermediaries: Price manipulation in an emerging stock market. Journal of Financial Economics 78, 203-241.

Klapper, L.F., Love, I. 2004. Corporate governance, investor protection, and performance in emerging markets. Journal of Corporate Finance 10(5), 703-728.

Kochanek, S. A., 1996. The rise of interest politics in Bangladesh. Asian Survey 36(7), 704722.

La Porta, R., Lopez-de-Silanes, F., Shleifer, A., Vishny, R., 1998. Law and finance. Journal of Political Economy 106, 1113-1155.

La Porta, R., Lopez-de-Silanes, F., Shleifer, A., 1999. Corporate ownership around the world. The Journal of Finance 54(2), 471-517.

La Porta, R., Lopez-de-Silanes, F., Shleifer, A., 2000. Investor protection and corporate governance. Journal of Financial Economics 58(1-2), 3-27.

Lee, K.S., Lim, G.H., Lim, W.S., 2003. Family business succession: Appropriation risk and choice of successor. Academy of Management Review 28(4), 657-666.

Levering, R., Moskowitz, M., 1993. The ten best companies to work for in America. Business and Society Review 85(2), 26-38.

Li, H., Meng, L., Wang, Q., Zhou, L., 2008. Political connections, financing and firm performance: Evidence from Chinese private firms. Journal of Development Economics 87(2), 283-299.

Mauro, P. 1995. Corruption and growth. Quarterly Journal of Economics 110(3), 681-712.

McConnell, J.J., Servaes, H. 1990. Additional evidence in equity ownership and corporate value. Journal of Financial Economic 27(2), 595-612.

Monem, R.M., 2013. Determinants of board structure: Evidence from Australia. Journal of Contemporary Accounting and Economics 9(1), 33-49.

Morck, R., Shleifer, A., Vishny, R. W., 1988. Management ownership and market valuation: An empirical analysis. Journal of Financial Economics 20(1-2), 293-315.

Moscetello, L., 1990. The Pitcairns want you. Family Business Magazine. February.

Myers, S. C., 1984. The capital structure puzzle. Journal of Finance 39(3), 575-592.

Papanek, H. 1972. Pakistan's big businessmen: Muslim separatism, entrepreneurship and partial modernization. Economic Development and Cultural Change 21(1), 1-32.

Perez-Gonzalez, F., 2006. Inherited control and firm performance? American Economic Review 96(5), 1559-1588. 
Pindado, J., Requejo, I., de la Torre, C. 2008. Ownership concentration and firm value: Evidence from Western European family firms. 8th Annual IFERA Conference, Breukelen, The Netherlands.

Reporters Without Borders, 2014. World Press Freedom Index 2014. Available at http://rsf.org/index2014/en-asia.php (last accessed on 25 March 2014)

Setia-Atmaja, L., Tanewski, G. A., Skully, M., 2009. The role of dividends, debt and board structure in the governance of family-controlled firms. Journal of Business Finance \& Accounting 36(7-8), 863-898.

Setia-Atmaja, L., Haman, J., Tanewski, G. 2011. The role of board independence in mitigating agency problem II in Australian family firms. The British Accounting Review 43(3), 230-246.

Shleifer, A., Vishny, R., 1986. Large shareholders and corporate control. Journal of Political Economy 94(3), 461-488.

Shujan, 2014. Shujan-a citizens' initiative for good governance. www.shujan.org (Last accessed on 22 April 2014).

Stein, J., 1988. Takeover threats and managerial myopia. Journal of Political Economy 96, 61-80.

Stigler, G. J., 1971. The theory of economic regulation. Bell Journal of Economics and Management Science 2(1), 3-21.

Tagiuri, R., Davis, J.A., 1996. Bivalent attributes of the family firm. Family Business Review 9(2), 199-208.

Transparency International, 2014. Corruption perceptions index. Transparency International, Available at http://cpi.transparency.org/cpi2013/results/. (Last accessed on 9 May 2014).

The Daily Star, 2014, "Hard for locals to speak up", 13 May 2014. Available at http://www.thedailystar.net/hard-for-locals-to-speak-up-23859 (Last accessed on 13 May 2014).

Uddin, S., Hopper, T., 2003. Accounting for privatisation in Bangladesh: Testing World Bank claims. Critical Perspectives on Accounting 14(7), 739-774.

Villalonga, B., Amit, R., 2006. How do family ownership, control and management affect firm value? Journal of Financial Economics 80(2), 385-417.

Ward, J.L., 1988. The special role of strategic planning for family businesses. Family Business Review 1(2), 105-117.

Ward, J.L., Aronoff, C.E., 1991. Trust gives you the advantage. Nation's Business 79(8), 4245 . 
White, H., 1980. A heteroskedasticity-consistent covariance matrix estimator and a direct test for heteroskedasticity. Econometrica 48(4), 817-838.

Wilcox, W., 1969, Pakistan: A decade of Ayub, Asian Survey 9(2), 87-93.

Williamson, O. E., 1967. Hierarchical control and optimum firm size. Journal of Political Economy 75(2), 123-138.

World Bank, 1997. Privatization experience in Bangladesh 1991-1996 (Dhaka: World Bank, 1997).

World Bank, 2009. Bangladesh: Corporate governance country assessment. Report on the Observance of Standards and Codes (ROSC).

Wright Jr., T., 1974, Indian Muslim refugees in the politics of Pakistan. The Journal of Commonwealth \& Comparative Politics 12(2), 189-205.

Wu, W., Wu, C., Zhou, C., Wu, J., 2012. Political connections, tax benefits and firm performance: Evidence from China. Journal of Accounting and Public Policy 31(3), 277-300. 
Table 1: Sample

Panel A: Sample distribution by year and ownership type (family vs. nonfamily firms)

\begin{tabular}{cccc}
\hline Year & Family firms & Nonfamily firms & Total \\
\hline 2005 & 86 & 46 & 132 \\
2006 & 86 & 47 & 133 \\
2007 & 84 & 45 & 129 \\
2008 & 86 & 48 & 134 \\
2009 & 77 & 49 & 126 \\
Total observations (firm-years) & 419 & 235 & 654 \\
\hline
\end{tabular}

Panel B: Distribution of firm-years by ownership type and political connections

\begin{tabular}{lccc}
\hline & Politically connected & Politically unconnected & Total \\
\hline Family firms & 260 & 159 & 419 \\
Nonfamily firms & 113 & 122 & 235 \\
Total firm-years & 373 & 281 & 654 \\
\hline
\end{tabular}

Panel C: Distribution of firm-years by industry sector and ownership type

\begin{tabular}{lrrrr}
\hline Sector & $\begin{array}{c}\text { Family } \\
\text { (Firm-years) }\end{array}$ & $\begin{array}{c}\text { Nonfamily } \\
\text { (Firm-years) }\end{array}$ & $\begin{array}{c}\text { Total } \\
\text { (Firm-years) }\end{array}$ & $\begin{array}{c}\text { Family firm-years in } \\
\text { each industry sector (\%) }\end{array}$ \\
\hline Cement & 17 & 20 & 37 & 45.95 \\
Ceramics & 13 & 6 & 19 & 68.42 \\
Engineering & 62 & 40 & 102 & 60.78 \\
Food & 68 & 45 & 113 & 60.18 \\
IT & 11 & 17 & 28 & 39.29 \\
Jute & 9 & 5 & 14 & 64.29 \\
Paper \& Printing & 10 & 0 & 10 & 100.00 \\
Miscellaneous & 22 & 30 & 52 & 42.31 \\
Pharmaceuticals & 62 & 30 & 92 & 67.39 \\
Service \& Real estate & 12 & 14 & 26 & 46.15 \\
Tannery & 9 & 16 & 25 & 36.00 \\
Textile & 124 & 12 & 136 & 91.18 \\
Total & 419 & 235 & 654 & \\
\hline
\end{tabular}

Panel D: Distribution of firm-years by industry sector and political connections

\begin{tabular}{lrrrr}
\hline Sector & $\begin{array}{c}\text { Firm-years with } \\
\text { political } \\
\text { connections }\end{array}$ & $\begin{array}{c}\text { Firm-years } \\
\text { without } \\
\text { political } \\
\text { connections }\end{array}$ & $\begin{array}{c}\text { Firm-years } \\
\text { in each } \\
\text { industry } \\
\text { sector }\end{array}$ & $\begin{array}{c}\text { Percent of industry } \\
\text { sector with political } \\
\text { connections }\end{array}$ \\
\hline Cement & 30 & 07 & 37 & 81.00 \\
Ceramics & 12 & 07 & 19 & 63.00 \\
Engineering & 69 & 33 & 102 & 68.00 \\
Food & 40 & 73 & 113 & 35.00 \\
IT & 13 & 15 & 28 & 43.00 \\
Jute & 09 & 05 & 14 & 64.00 \\
Paper \& Printing & 10 & 00 & 10 & 100.00 \\
Pharmaceuticals & 47 & 45 & 92 & 51.00 \\
Service \& Real estate & 19 & 07 & 26 & 73.00 \\
Tannery & 11 & 14 & 25 & 44.00 \\
Textile & 85 & 51 & 136 & 63.00 \\
Miscellaneous & 28 & 24 & 52 & 54.00 \\
Total & 373 & 281 & 654 & 57.00
\end{tabular}


Table 2: Descriptive statistics

\begin{tabular}{lrrrrr}
\hline \multicolumn{1}{c}{ Variables } & \multicolumn{1}{c}{ Mean } & Median & Std. Dev. & 1st Quartile & 3rd Quartile \\
\hline Tobin's $q$ & 1.508 & 1.118 & 1.200 & 0.855 & 1.671 \\
ROA & 0.073 & 0.070 & 0.093 & 0.033 & 0.113 \\
FOWN & 0.290 & 0.319 & 0.219 & 0.067 & 0.478 \\
FF & 0.641 & 1.000 & 0.480 & 0.000 & 1.000 \\
PCON & 0.570 & 1.000 & 0.495 & 0.000 & 1.000 \\
GROWTH & 0.116 & 0.048 & 0.341 & -0.022 & 0.146 \\
LEV & 0.749 & 0.604 & 0.789 & 0.429 & 0.801 \\
RISK & 0.028 & 0.027 & 0.024 & 0.020 & 0.036 \\
AGE & 22.989 & 23.000 & 10.940 & 13.000 & 29.000 \\
FSIZE (in million Taka) & $1,507.0$ & 483.2 & $3,304.2$ & 201.5 & $1,202.3$ \\
YEP/HP & 0.801 & 0.827 & 0.166 & 0.692 & 0.947 \\
Firm-years & 654 & 654 & 654 & 654 & 654 \\
\hline
\end{tabular}

Variable definitions: Tobin's $q$ is the market value of equity plus the book value of total debt divided by the book value of total assets. ROA is the ratio of earnings before interest and taxes divided by the book value of total assets. FOWN is a continuous measure of family ownership of a business; it is the percentage of shares collectively owned by members of the same family. If multiple families own shares in a firm, we consider the share ownership by the largest family-owner only. $F F$ is a binary measure of family ownership; $F F$ is set equal to 1 for family firms and 0 otherwise. We classify a firm as a family firm if (1) the members of the same family jointly hold at least $20 \%$ of the firm's shares or voting rights (either directly or indirectly) and (2) at least one family member is the CEO of the firm or a member of the board of directors. PCON is an indicator variable set equal to 1 for politically connected firms and 0 otherwise. We consider a firm to be politically connected when at least one of its major shareholders or a member of its board or the CEO is or was a member of the parliament, a minister or closely associated with a political party or a politician. GROWTH of a firm is measured by the firm's total assets growth ratio over the last fiscal year. $L E V$ is the ratio of book value of total debts to book value of total assets. RISK is the standard deviation of the firm's daily stock return over the prior 12-month period. AGE is the number of years since firm inception. FSIZE is the book value of assets in millions of Taka (Bangladesh currency). 
Table 3: Pearson's Correlation matrix

\begin{tabular}{|c|c|c|c|c|c|c|c|c|c|c|c|}
\hline & Tobin's q & $R O A$ & FOWN & $F F$ & PCON & GROWTH & $L E V$ & RISK & $A G E$ & FSIZE & YEP/HP \\
\hline Tobin's q & 1.000 & & & & & & & & & & \\
\hline$R O A$ & -0.001 & 1.000 & & & & & & & & & \\
\hline FOWN & -0.162 & $0.084 * *$ & 1.000 & & & & & & & & \\
\hline$F F$ & -0.155 & 0.084 & $0.865 * * *$ & 1.000 & & & & & & & \\
\hline PCON & $-0.071^{*}$ & 0.030 & $0.189 * * *$ & $0.168 * * *$ & 1.000 & & & & & & \\
\hline GROWTH & -0.007 & $0.102 * * *$ & $0.069 *$ & 0.051 & 0.019 & 1.000 & & & & & \\
\hline$L E V$ & $0.577 * * *$ & $-0.406^{* * *}$ & $-0.068^{*}$ & $-0.065^{*}$ & 0.010 & -0.052 & 1.000 & & & & \\
\hline RISK & 0.038 & $-0.134 * * *$ & $-0.114 * * *$ & $-0.117 * * *$ & 0.001 & 0.025 & 0.022 & 1.000 & & & \\
\hline$A G E$ & -0.007 & -0.01 & $-0.180 * * *$ & $-0.097 * * *$ & -0.058 & $-0.068 *$ & $0.075^{*}$ & -0.004 & 1.000 & & \\
\hline FSIZE & 0.013 & $0.103 * * *$ & -0.048 & $-0.066^{*}$ & $0.107 * * *$ & $0.172 * * *$ & $-0.072 *$ & -0.034 & 0.040 & 1.000 & \\
\hline YEP/HP & 0.044 & $0.193 * * *$ & 0.062 & $0.075^{*}$ & -0.035 & 0.067 & -0.035 & $-0.284 * * *$ & $0.077^{*}$ & 0.047 & 1.000 \\
\hline
\end{tabular}

*Significant at the $10 \%$ level, ** Significant at the $5 \%$ level, ***Significant at the $1 \%$ level. All tests are two-tailed tests.

Variable definitions: Tobin's $q$ is the market value of equity plus the book value of total debt divided by the book value of total assets. $R O A$ is the ratio of earnings before interest and taxes divided by the book value of total assets. FOWN is a continuous measure of family ownership of a business; it is the percentage of shares collectively owned by members of the same family. If multiple families own shares in a firm, we consider the share ownership by the largest family owner only. $F F$ is a binary measure of family ownership; $F F$ is set equal to 1 for family firms and 0 otherwise. We classify a firm as a family firm if (1) the members of the same family jointly hold at least $20 \%$ of the firm's shares or voting rights (either directly or indirectly) and (2) at least one family member is the CEO of the firm or a member of the board of directors. PCON is an indicator variable set equal to 1 for politically connected firms and 0 otherwise. We consider a firm to be politically connected when at least one of its major shareholders or a member of its board or the CEO is or was a member of the parliament, a minister or closely associated with a political party or a politician. GROWTH of a firm is measured by the firm's total assets growth ratio over the last fiscal year. $L E V$ is the ratio of book value of total debts to book value of total assets. $R I S K$ is the standard deviation of the firm's daily stock return over the prior 12-month period. AGE is the number of years since firm inception. FSIZE is the book value of assets in millions of Taka (Bangladesh currency). YEP/HP is the fiscal year-end share price $(Y E P)$ of a firm scaled by its highest share price of the fiscal year $(H P)$ 
Table 4: Family firms and performance

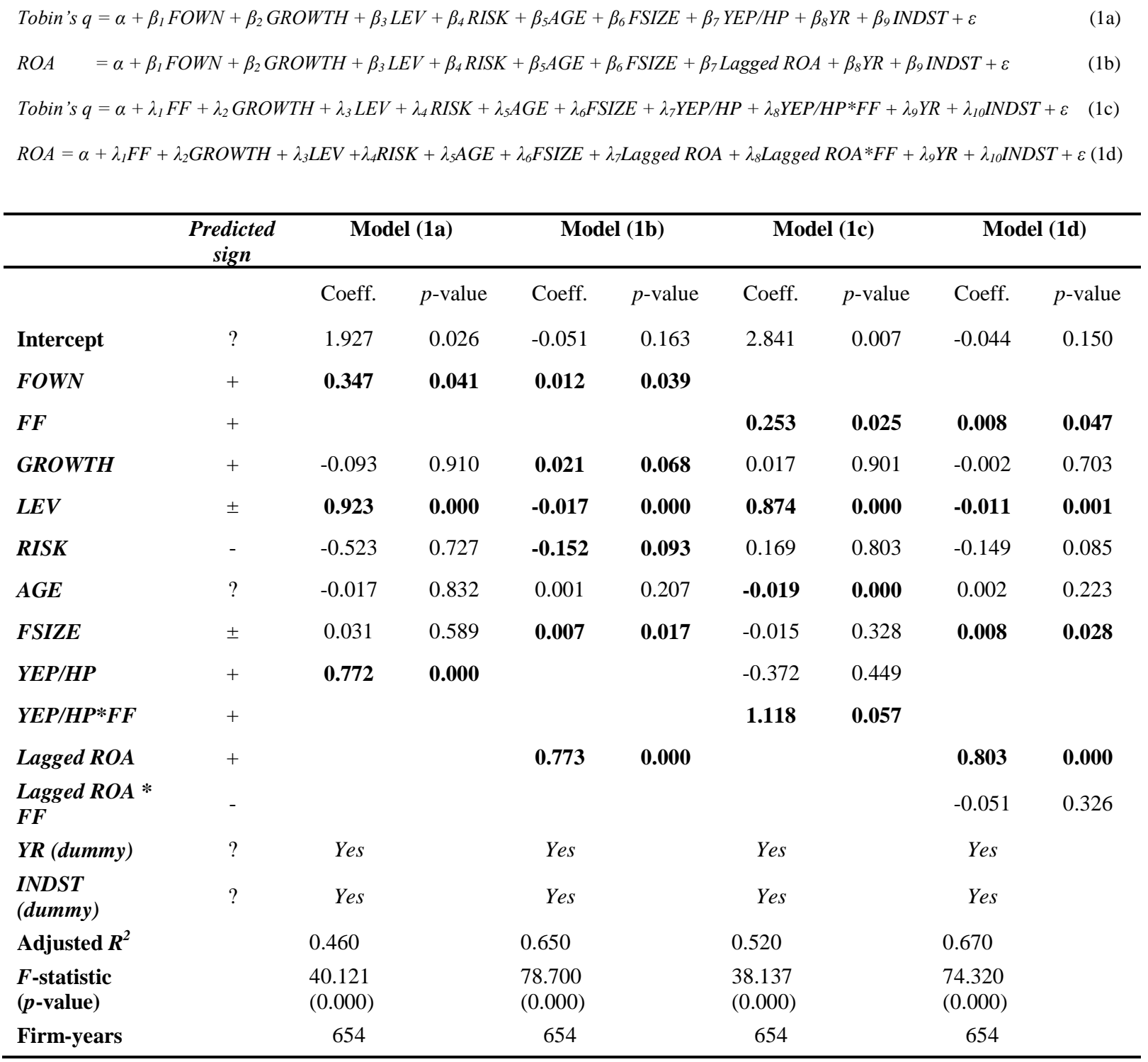

Variable definitions: Tobin's $q$ is the market value of equity plus the book value of total debt divided by the book value of total assets. ROA is the ratio of earnings before interest and taxes divided by the book value of total assets. FOWN is a continuous measure of family ownership of a business; it is the percentage of shares collectively owned by members of the same family. If multiple families own shares in a firm, we consider the share ownership by the largest family-owner only. $F F$ is a binary measure of family ownership; $F F$ is set equal to 1 for family firms and 0 otherwise. We classify a firm as a family firm if (1) the members of the same family jointly hold at least $20 \%$ of the firm's shares or voting rights (either directly or indirectly) and (2) at least one family member is the CEO of the firm or a member of the board of directors. $P C O N$ is an indicator variable set equal to 1 for politically connected firms and 0 otherwise. We consider a firm to be politically connected when at least one of its major shareholders or a member of its board or the CEO is or was a member of the parliament, a minister or closely associated with a political party or a politician. GROWTH of a firm is measured by the firm's assets growth ratio. $L E V$ is the ratio of book value of total debts to book value of total assets. RISK is the standard deviation of the firm's daily stock return over the prior 12-month period. AGE is the number of years since firm inception. FSIZE is the book value of assets. $Y E P / H P$ is the fiscal year-end share price $(Y E P)$ of a firm scaled by its highest share price of the fiscal year $(H P)$. Lagged ROA is the ROA of the previous fiscal year. We apply White's (1980) heteroskedasticityconsistent standard errors for all regressions, and standard errors are clustered at the firm level. 
Table 5: Effect of political connections on the performance of family and nonfamily firms

Tobin's $q=\alpha+\beta_{1} F O W N+\beta_{2} P C O N+\beta_{3} P C O N * F O W N+\beta_{4} G R O W T H+\beta_{5} L E V+\beta_{6} R I S K+\beta_{7} A G E+\beta_{8} F S I Z E+\beta_{9} Y E P / H P+\beta_{10} Y E P / H P * F O W N+\beta_{11} Y R+\beta_{12} I N D S T+\varepsilon$

$R O A=\alpha+\beta_{1} F O W N+\beta_{2} P C O N+\beta_{3} P C O N * F O W N+\beta_{4} G R O W T H+\beta_{5} L E V+\beta_{6} R I S K+\beta_{7} A G E+\beta_{8} F S I Z E+\beta_{9} L a g g e d$ ROA $+\beta_{10}$ Lagged ROA $* F O W N+\beta_{11} Y R+\beta_{12} I N D S T+\varepsilon$

Tobin's $q=\alpha+\beta_{1} F F+\beta_{2} P C O N+\beta_{3} P C O N * F F+\beta_{4} G R O W T H+\beta_{5} L E V+\beta_{6} R I S K+\beta_{7} A G E+\beta_{8} F S I Z E+\beta_{9} Y E P / H P+\beta_{10} Y E P / H P * F F+\beta_{11} Y R+\beta_{12} I N D S T+\varepsilon$

$R O A=\alpha+\beta_{1} F F+\beta_{2} P C O N+\beta_{3} P C O N * F F+\beta_{4} G R O W T H+\beta_{5} L E V+\beta_{6} R I S K+\beta_{7} A G E+\beta_{8} F S I Z E+\beta_{9} L a g g e d$ ROA $+\beta_{10} L a g g e d$ ROA $* F F+\beta_{11} Y R+\beta_{12} I N D S T+\varepsilon$

Tobin's $q=\alpha+\beta_{1} P C O N+\beta_{2}$ GROWTH $+\beta_{3} L E V+\beta_{4} R I S K+\beta_{5} A G E+\beta_{6} F S I Z E+\beta_{7} Y E P / H P+\beta_{8} Y R+\beta_{9} I N D S T+\varepsilon$

$R O A=\alpha+\beta_{1} P C O N+\beta_{2}$ GROWTH $+\beta_{3} L E V+\beta_{4} R I S K+\beta_{5} A G E+\beta_{6}$ FSIZE $+\beta_{7}$ Lagged ROA $+\beta_{8} Y R+\beta_{9} I N D S T+\varepsilon$

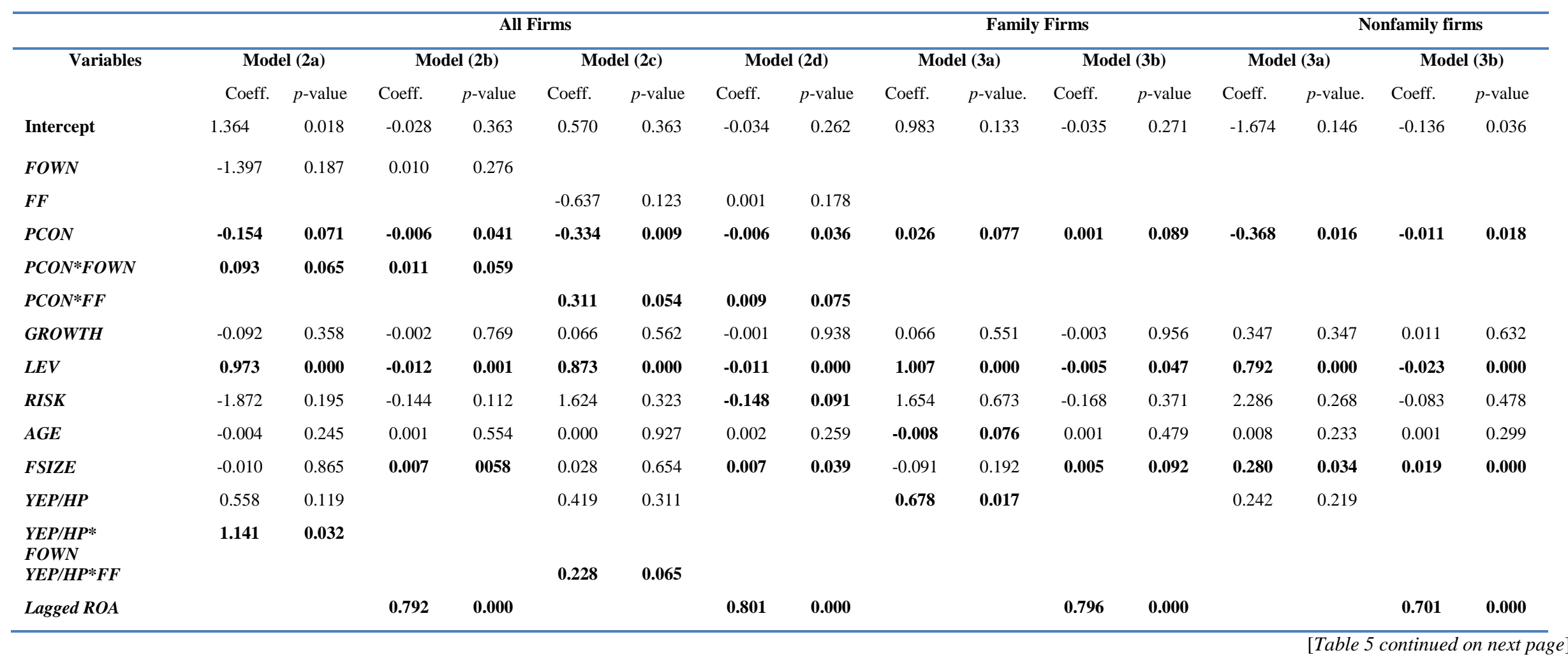


Table 5 (continued)

\begin{tabular}{|c|c|c|c|c|c|c|c|c|c|}
\hline $\begin{array}{l}\text { Lagged } \\
\text { ROA*FOWN }\end{array}$ & & 0.035 & 0.081 & & & & & & \\
\hline Lagged $R O A * F F$ & & & & 0.022 & 0.062 & & & & \\
\hline YR (dummy) & Yes & Yes & Yes & Yes & & Yes & Yes & Yes & Yes \\
\hline INDST(dummy) & Yes & Yes & Yes & Yes & & Yes & Yes & Yes & Yes \\
\hline Adjusted $\mathbf{R}^{2}$ & 0.525 & 0.667 & 0.353 & 0.671 & & 0.286 & 0.675 & 0.408 & 0.687 \\
\hline$F$-statistic & 35.350 & 132.083 & 36.693 & 130.092 & & 24.870 & 125.201 & 24.084 & 70.997 \\
\hline Prob (F-statistic) & 0.000 & 0.000 & 0.000 & 0.000 & & 0.000 & 0.000 & 0.000 & 0.000 \\
\hline Firm-years & 654 & 654 & 654 & 654 & & 419 & 419 & 235 & 235 \\
\hline
\end{tabular}

Variable definitions: Tobin's $q$ is the market value of equity plus the book value of total debt divided by the book value of total assets. ROA is the ratio of earnings before interest and taxes divided by the book value of total assets. FOWN is a continuous measure of family ownership of a business; it is the percentage of shares collectively owned by members of the same family. If multiple families own shares in a firm, we consider the share ownership by the largest family-owner only. $F F$ is a binary measure of family ownership; $F F$ is set equal to 1 for family firms and 0 otherwise. We classify a firm as a family firm if (1) the members of the same family jointly hold at least $20 \%$ of the firm's shares or voting rights (either directly or indirectly) and (2) at least one family member is the CEO of the firm or a member of the board of directors. PCON is an indicator variable set equal to 1 for politically connected firms and 0 otherwise. We consider a firm to be politically connected when at least one of its major shareholders or a member of its board or the CEO is or was a member of the parliament, a minister or closely associated with a political party or a politician. GROWTH of a firm is measured by the firm's assets growth ratio. $L E V$ is the ratio of book value of total debts to book value of total assets. RISK is the standard deviation of the firm's daily stock return over the prior 12 -month period. $A G E$ is the number of years since firm inception. FSIZE is the book value of assets. $Y E P / H P$ is the fiscal year-end share price $(Y E P)$ of a firm scaled by its highest share price of the fiscal year $(H P)$. Lagged ROA is the ROA of the previous fiscal year. We apply White's (1980) heteroskedasticity-consistent standard errors for all regressions, and standard errors are clustered at the firm level. Two-tailed $p$-values are reported in parentheses. 
Table 6: Family firms, political connections and performance: Generations of family firms

Tobin's $q=\alpha+\beta_{1} P C O N+\beta_{2}$ FIRST_GEN $+\beta_{3} P C O N^{*} F I R S T \_G E N+\beta_{4} G R O W T H+\beta_{5} L E V+\beta_{6} R I S K+\beta_{7} A G E+\beta_{8} F S I Z E+\beta_{9} Y E P / H P+\beta_{10} Y R+\beta_{I I} I N D S T+\varepsilon$

$R O A=\alpha+\beta_{1} P C O N+\beta_{2} F I R S T_{-} G E N+\beta_{3} P C O N * F I R S T \_G E N+\beta_{4} G R O W T H+\beta_{5} L E V+\beta_{6} R I S K+\beta_{7} A G E+\beta_{8} F S I Z E+\beta_{9} L a g g e d R O A+\beta_{10} Y R+\beta_{1 I} I N D S T+\varepsilon$

Tobin's $q=\alpha+\beta_{1} P C O N+\beta_{2} G R O W T H+\beta_{3} L E V+\beta_{4} R I S K+\beta_{5} A G E+\beta_{6} F S I Z E+\beta_{7} Y E P / H P+\beta_{8} Y R+\beta_{9} I N D S T+\varepsilon$

$R O A=\alpha+\beta_{1} P C O N+\beta_{2} G R O W T H+\beta_{3} L E V+\beta_{4} R I S K+\beta_{5} A G E+\beta_{6} F S I Z E+\beta_{7}$ Lagged ROA $+\beta_{8} Y R+\beta_{9} I N D S T+\varepsilon$

\begin{tabular}{|c|c|c|c|c|c|c|c|c|c|c|c|c|}
\hline \multirow[b]{3}{*}{ Variable } & \multicolumn{4}{|c|}{ All Family firms } & \multicolumn{4}{|c|}{ First-generation family firms } & \multicolumn{4}{|c|}{ Descendant family firms } \\
\hline & \multicolumn{2}{|c|}{ Model (4a) } & \multicolumn{2}{|c|}{ Model (4b) } & \multicolumn{2}{|c|}{ Model (4c) } & \multicolumn{2}{|c|}{ Model (4d) } & \multicolumn{2}{|c|}{ Model (4c) } & \multicolumn{2}{|c|}{ Model (4d) } \\
\hline & Coefficient & Prob. & Coefficient & Prob. & Coefficient & Prob. & Coefficient & Prob. & Coefficient & Prob. & Coefficient & Prob. \\
\hline Intercept & 0.971 & 0.135 & -0.032 & 0.053 & 0.642 & 0.481 & -0.050 & 0.221 & 2.466 & 0.002 & 0.067 & 0.304 \\
\hline PCON & 0.289 & 0.097 & 0.013 & 0.067 & 0.037 & 0.075 & 0.001 & 0.089 & -0.288 & 0.026 & -0.232 & 0.087 \\
\hline FIRST_GEN & 0.000 & 0.998 & 0.003 & 0.113 & & & & & & & & \\
\hline PCON*FIRST_GEN & 0.396 & 0.053 & 0.298 & 0.076 & & & & & & & & \\
\hline GROWTH & 0.085 & 0.436 & -0.001 & 0.976 & 0.204 & 0.232 & 0.001 & 0.806 & 0.025 & 0.800 & -0.002 & 0.791 \\
\hline$L E V$ & 1.042 & 0.000 & 0.005 & 0.229 & 1.420 & 0.000 & -0.014 & 0.062 & 0.736 & 0.000 & 0.017 & 0.032 \\
\hline RISK & 1.448 & 0.713 & -0.143 & 0.449 & -0.531 & 0.923 & -0.427 & 0.062 & 16.229 & 0.304 & 0.156 & 0.680 \\
\hline$A G E$ & -0.005 & 0.331 & 0.001 & 0.772 & -0.015 & 0.020 & 0.001 & 0.045 & 0.017 & 0.001 & -0.001 & 0.089 \\
\hline FSIZE & -0.099 & 0.171 & 0.006 & 0.081 & -0.049 & 0.609 & 0.008 & 0.057 & 0.374 & 0.000 & -0.007 & 0.369 \\
\hline YEP/HP & 0.661 & 0.020 & & & 0.618 & 0.082 & & & 0.922 & 0.010 & & \\
\hline Lagged ROA & & & 0.782 & 0.000 & & & 0.776 & 0.000 & & & 0.742 & 0.000 \\
\hline YR (dummy) & Yes & & Yes & & Yes & & Yes & & Yes & & Yes & \\
\hline INDST(dummy) & Yes & & Yes & & Yes & & Yes & & Yes & & Yes & \\
\hline Adjusted $\mathbf{R}^{2}$ & 0.297 & & 0.675 & & 0.235 & & 0.671 & & 0.656 & & 0.701 & \\
\hline$F$-statistic & 20.582 & & 97.656 & & 14.353 & & 89.840 & & 31.785 & & 41.365 & \\
\hline Prob (F-statistic) & 0.000 & & 0.000 & & 0.000 & & 0.000 & & 0.000 & & 0.000 & \\
\hline Firm-years & 419 & & 419 & & 305 & & 305 & & 114 & & 114 & \\
\hline
\end{tabular}

[Table 6 continues on next page.] 
Table 6 (continued)

Variable definitions: Tobin's $q$ is the market value of equity plus the book value of total debt divided by the book value of total assets. ROA is the ratio of earnings before interest and taxes divided by the book value of total assets. FOWN is a continuous measure of family ownership of a business; it is the percentage of shares collectively owned by members of the same family. If multiple families own shares in a firm, we consider the share ownership by the largest family-owner only. $F F$ is a binary measure of family ownership; $F F$ is set equal to 1 for family firms and 0 otherwise. We classify a firm as a family firm if (1) the members of the same family jointly hold at least $20 \%$ of the firm's shares or voting rights (either directly or indirectly) and (2) at least one family member is the CEO of the firm or a member of the board of directors. PCON is an indicator variable set equal to 1 for politically connected firms and 0 otherwise. We consider a firm to be politically connected when at least one of its major shareholders or a member of its board or the CEO is or was a member of the parliament, a minister or closely associated with a political party or a politician. GROWTH of a firm is measured by the firm's assets growth ratio. $L E V$ is the ratio of book value of total debts to book value of total assets. RISK is the standard deviation of the firm's daily stock return over the prior 12month period. $A G E$ is the number of years since firm inception. FSIZE is the book value of assets. YEP/HP is the fiscal year-end share price (YEP) of a firm scaled by its highest share price of the fiscal year $(H P)$. Lagged ROA is the ROA of the previous fiscal year. We apply White's (1980) heteroskedasticity-consistent standard errors for all regressions, and standard errors are clustered at the firm level. Two-tailed $p$-values are reported in parentheses. 